\title{
Navigating housing affordability in Rwanda: Challenges and facilitation strategies
}

\author{
Josephine M. Malonza ${ }^{1 *}$, Nathan Kibwami ${ }^{2,3}$ and Philip O. Lawal ${ }^{3}$ \\ ${ }^{1}$ University of Rwanda, Department of Architecture, P. O. Box 4285, Kigali, Rwanda \\ ${ }^{2}$ Makerere University, Department of Construction Economics and Management, P.O. Box, 7062, Kampala, Uganda \\ ${ }^{3}$ University of Rwanda, Department of Construction Management, P. O. Box 4285, Kigali, Rwanda \\ *Corresponding Author: jmalonza@ur.ac.rw, josemwongeli@yahoo.com
}

DOI: $10.4314 /$ rjeste.v4i1.2

https://dx.doi.org/10.4314/rjeste.v4i1.2

\begin{abstract}
Housing and its affordability have, of recent, been of great concern to various stakeholders, especially in the developing world. Consequently, contributing aspects such as construction/tenancy costs, sustainability, environmental impact, and availability of credit facilities with a host of other factors, have dominated contemporary research. Various studies suggest that addressing affordable housing requires understanding the contextual factors that impact affordability of housing. Such studies have not been known to succinctly treat the context of Rwanda. This paper aimed at exploring the perspectives of housing affordability in Rwanda with a view of eliciting the status, challenges, and prospects. The objectives included description of the current status of housing, identifying the challenges of providing affordable housing, and proposals of strategies to enhance its provision. Data, such as for workers' salary, costs of house construction, inflationary trends and the number of housing units per income group, were sought for and obtained either from the archives of various stakeholder organizations or by interviewing key officers concerned with housing. Descriptive statistics and thematic analyses were employed in analyzing the data in order to fulfil the objectives of the study. It was found that home ownership and tenure statistics varied, yet housing demand was on the rise. Foremost challenges, among others, were recorded to be scarcity and costly plots of land, compounded with costly building materials. In addition, the purchasing power of the local currency depreciated fast over time, thereby making good quality housing unaffordable for the majority of Rwandans. Localizing policy to enhance public awareness, resolving the issue of high cost of construction materials, and coming up with innovative interventions on land costs, were among the key strategies to facilitate housing affordability.
\end{abstract}


Keywords: Affordable housing; Housing demand; Housing finance; Low-cost housing; Housing policy; Rwanda

\section{Introduction}

Housing affordability continues to be one of the key focus for contemporary housing studies and policy, not only in the developing world but also the developed world alike. For instance, in the USA, reports suggest that affordable housing needs are persistently on the rise (HUD, 2007). In the developing world, a number of studies have explored the concept of housing affordability. Cai $\& \mathrm{Lu}$ (2015) studied housing affordability, going beyond the common price and income terms, to further include four concepts of accessibility, amenity and adequacy in the context of a Chinese case study. Acolin \& Green (2017) argued that combining housing costs, transportation costs and including opportunity cost associated with commuting time, all go a long way in providing a novel measure of housing affordability. Gan et al. (2017) identified several sustainability performance indicators which, the study argued, would be key in guiding the development of affordable housing. Ram \& Needham (2016) investigated commercial developers' interest in provision of affordable housing in India and discovered that if some constraints such as credit, availability of land and lengthy bureaucratic approvals for construction were to be addressed, the developers would commercially avail affordable housing. These studies, among others, suggest that addressing affordable housing requires understanding the contextual factors that hinder or promote affordability of housing. To date, none of such studies have been carried out in the context of Rwanda, yet this country, despite its appreciable economic growth, continues to grapple with provision of affordable housing to its increasing urbanized population. This paper sought to fill this gap.

The increase in the rate of urbanization and the pooled effect of the population upsurge has thrown Rwanda into acute housing supply. Benken (2017) opined that the systemic eradication or largescale displacement of informal settlements to make way for modern and productive urban areas impacts significantly on the consequent trend of urbanization in cities. This has had serious implications for housing provision in both quantitative and qualitative terms, that is, absolute shortage in housing needed to meet the demand of the rising population, and poor-quality services in the existing housing stock, respectively (Olayiwola, 2013). Currently, the annual housing supply in Rwanda is about 1000 units, leading to an annual deficit of about 30,000 units (Claude, 2015). 
Consequently, this introduces raptures between housing supply and demand in Rwanda. Against the above background, this paper explores the perspectives of housing affordability in Rwanda with a view to eliciting the status, challenges, and prospects. To achieve this aim, the following research objectives were formulated:

1. To unpack the determinants of housing affordability in Rwanda

2. To identify the challenges associated with providing affordable housing,

3. To propose strategies that can enhance facilitation policy formulation towards affordable housing.

The Government of Rwanda, in its National Housing Policy, outlines four different segments of Rwanda's housing market (GOR, 2015). The first category is social housing to provide for very poor households, earning less than RWF35, 000 (US\$36) per month and not able to meet their own housing needs. This type of demand should ideally be met by the government through a subsidy system yet to be determined. The second category is 'Affordable housing', which is the largest segment of the market, and is meant for households earning above RWF 35,000 but below RWF200, 000 (US\$36 to US\$210) per month. The third category is 'Mid-Range housing' for households earning above RWF200000 up to RWF900, 000 (US\$210 to US\$947) per month and the fourth category is 'Premium housing' for those earning above RWF900, 000 (greater than US\$947) per month. Of all these four segments, only the fourth segment is currently covered by existing mortgage financing, which essentially creates a housing finance gap problem.

A housing market study for Kigali conducted in 2012 and reported in the Rwanda Habitat III Report (2015) estimated total housing needs for the capital of almost 460,000 units between 2012 and 2022, of which almost 345000 units would need to be newly constructed. Collectively, for Kigali city and six secondary cities (seen as the total urban areas of Rwanda) to cater for the housing demand in Rwanda, it has been suggested that a similar number of additional housing units will need to be constructed outside Kigali. This translates into an average of 69,000 units per year over the ten-year period from 2012 to 2022 (GOR 2015). 


\section{Determinants of Housing Affordability in Rwanda}

This section discusses the various contextual challenges the housing sector in Rwanda is confronted with, in the path to attaining housing affordability for her population. There is need to rethink the way to formulate, implement and manage housing policies as drivers for sustainable development.

Table 1. Determinants of Housing Affordability in Rwanda

\begin{tabular}{|c|c|c|c|}
\hline No. & Determinant & Description & References \\
\hline 2.1 & $\begin{array}{l}\text { Availability of } \\
\text { Land }\end{array}$ & $\begin{array}{l}\text { Land is one of the most vital resources of } \\
\text { housing production and its costs and } \\
\text { documentation account in most cases, for a } \\
\text { substantial part of the amount required for } \\
\text { housing development. } \\
\text { Studies suggest that robust legal frameworks } \\
\text { are necessary to facilitate affordable and } \\
\text { secured access to land }\end{array}$ & $\begin{array}{l}\text { Nubi, } 2000 \\
\text { UN-Habitat, } 2011 \\
\text { Adesoji, } 2011 .\end{array}$ \\
\hline 2.2 & $\begin{array}{l}\text { Cost of } \\
\text { construction } \\
\text { materials }\end{array}$ & $\begin{array}{l}\text { The last decade has seen a significant rise in } \\
\text { the quantities of imported construction } \\
\text { materials to Rwanda from especially Kenya, } \\
\text { Uganda, China, Belgium and the United Arab } \\
\text { Emirates }\end{array}$ & Byusa, 2010 \\
\hline 2.3 & $\begin{array}{l}\text { Availability of } \\
\text { Housing } \\
\text { Finance }\end{array}$ & $\begin{array}{l}\text { Rwanda suffers an acute deficit of affordable } \\
\text { housing largely due to the inability of the } \\
\text { finance sector to attend to low-income } \\
\text { households. } \\
\text { In Rwanda, housing can be financed through } \\
\text { only two formal sources, namely commercial } \\
\text { banks and Banque Rwandaise de } \\
\text { Development (BRD). }\end{array}$ & $\begin{array}{l}\text { Tsinda \& Mugisha, } \\
2018 \\
\text { Interview } 8\end{array}$ \\
\hline 2.4 & $\begin{array}{l}\text { Income Earning } \\
\text { Capacity of } \\
\text { Workers }\end{array}$ & $\begin{array}{l}\text { The Rwandan National Housing Policy } \\
\text { categorically stated that the Rwandan } \\
\text { workers generally have incomes that are not } \\
\text { favorable to obtaining housing loans that can } \\
\text { fetch them decent housing. }\end{array}$ & $\begin{array}{l}\text { GOR, } 2015 \\
\text { The World Bank, } \\
2018 \\
\text { Buckley, } 2014\end{array}$ \\
\hline
\end{tabular}




\begin{tabular}{|l|l|l|l|}
\hline $\mathbf{2 . 5}$ & $\begin{array}{l}\text { Macroeconomic } \\
\text { Considerations }\end{array}$ & $\begin{array}{l}\text { The level of income is very low for the } \\
\text { Rwandan worker }\end{array}$ & $\begin{array}{l}\text { There exists a strong link between inflation } \\
\text { and prices of housing. } \\
\text { High inflation and interest as well as other } \\
\text { macro-variables do not favor affordable } \\
\text { housing, since real payments on a long term } \\
\text { fixed-rate mortgage are front-loaded. }\end{array}$ \\
$\begin{array}{l}\text { High inflation leads to reduced quantity of } \\
\text { housing. Inflation also has direct impact on } \\
\text { the interest rate charged by mortgage lenders } \\
\text { as well as value of later mortgage payments }\end{array}$ & Boamah, \\
\hline
\end{tabular}

Source: Compiled by Authors

Focusing on the opportunity of obtaining loans for home ownership, the following scenario illustrates how it is impracticable for a wage earner to secure housing loan, construct his house and repay the loan in his working life. Assume a middle-income salary earner of Frw 500,000 per month (Frw 6,000,000 per annum) as presented in Table 2 below.

Table 2. Financing Home Ownership via Housing Loan in Rwanda

\begin{tabular}{llc}
\hline Income - expenditure narration & Amount involved (Frw) \\
\hline Salary per annum & Expenditure & Income \\
\hline Purchase of a 15x20m plot of land outside the city & $2,500,0000,000$ \\
\hline Design of the Building \& Planning permit & $2,500,000$ \\
\hline Construction cost of 3-bedroom flat with external works & $20,000,00$ \\
\hline Total & $\mathbf{2 5 , 0 0 0 , 0 0 0}$ \\
\hline
\end{tabular}




\section{Materials and Methods}

\subsection{Data collection and preparation}

A descriptive mixed-methods research design that involved collecting different forms of data both quantitative and qualitative - was followed to allow the research to maximize on the impact of both (Saunders et al., 2016), in order to fulfill the aim and objectives of this study. Mixed methods are useful in clarifying and answering more questions from different perspectives in order to enhance the validity of the research findings. Specifically, this study used a concurrent mixed methods design (see Creswell, 2014), interpreting both quantitative and qualitative data sets in order to allow a comprehensive analysis of housing affordability in Rwanda, in comparison to use of a single methods design.

Descriptive research design helps to provide answers to questions of who, what, when, where, and how, that are associated with a research problem. These questions are useful in obtaining information on the current status of a phenomena such as describing "what exists", with respect to variables or conditions in a situation (Denscombe, 2010; Fellows \& Liu, 2009). The authors believed that there exist multiple realities around housing affordability and the same is both historically and socially situated as well as significantly shaped by the everyday experiences of city residents. The mixed-method approach therefore enabled the research to attain more contextually significant discovery and conclusions.

In order to implement the descriptive mixed-method design, literature and archival data retrieved from public authorities such as the National Institute of Statistics of Rwanda (NISR), and organized private sector were reviewed to understand the current status of housing in Rwanda. These secondary data also included interview data that were extracted verbatim from credible sources. Consequently, the challenges and strategies that can facilitate provision of affordable housing were identified.

\subsection{Characteristics of respondents}

The information garnered was augmented by carrying out eight key informant interviews with purposely selected participants, as summarized in Error! Reference source not found.. In-depth interviews were also conducted in order to elicit key issues around facilitation of housing affordability in Rwanda. 
Rwanda Journal of Engineering, Science, Technology and Environment, Volume 4, Issue 1, June 2021 eISSN: 2617-233X | print ISSN: 2617-2321

Table 3. Summary of in-depth interview respondents

\begin{tabular}{llll}
\hline S/N & $\begin{array}{l}\text { Respondent's } \\
\text { designation }\end{array}$ & Affiliation & Purpose of selection \\
\hline 1 & Architect 1 & Eco-Build consultancy firm & $\begin{array}{l}\text { A leading housing design consultant } \\
\text { in Rwanda }\end{array}$ \\
\hline 2 & Architect 2 & $\begin{array}{l}\text { Architectural Association of } \\
\text { Kenya }\end{array}$ & $\begin{array}{l}\text { Champion of affordable and social } \\
\text { housing in Eastern Africa }\end{array}$ \\
\hline 3 & Architect 3 & City of Kigali & $\begin{array}{l}\text { Practitioner and policy maker on } \\
\text { housing in Rwanda }\end{array}$ \\
\hline 4 & Project Manager & $\begin{array}{l}\text { RD \& Partners consultancy } \\
\text { firm }\end{array}$ & $\begin{array}{l}\text { A leading housing project manager } \\
\text { in Rwanda }\end{array}$ \\
\hline 5 & Research Analyst & $\begin{array}{l}\text { Institute of Policy Analysis } \\
\text { and Research }\end{array}$ & $\begin{array}{l}\text { A leading research analyst on } \\
\text { housing in Rwanda }\end{array}$ \\
\hline 6 & Social Scientist 1 & $\begin{array}{l}\text { Rwanda Institute for } \\
\text { Sustainable Development }\end{array}$ & $\begin{array}{l}\text { Community voices on land and } \\
\text { housing issues in Rwanda }\end{array}$ \\
\hline 7 & Social Scientist 2 & Rwanda Women Network & $\begin{array}{l}\text { Inclusivity of communities to } \\
\text { housing issues in Rwanda }\end{array}$ \\
\hline 8 & Retail Banker & GT Bank & $\begin{array}{l}\text { Provides Mortgage opportunities for } \\
\text { housing in Rwanda }\end{array}$ \\
\hline
\end{tabular}

Source: Authors' Fieldwork

The data gathered from in-depth interviews were qualitative and as such, content analysis, which is a qualitative data analysis technique, was used. The results were presented by showing codes with exemplars, descriptive excerpts from interviews, and coding frequency (see Hsieh \& Shannon, 2005; Curtis et al., 2001). As such, in presenting the results of this research, the authors qualitatively discussed the voices from the field and also grouped the responses into themes hence making the results easier to conceptualize. This analysis provided a rich discussion where primary data from the interviews were used to supplement discussions garnered from the literature.

\section{Provision of affordable Housing in Rwanda}

For decent housing to be sustainable, it will need to be affordable. The study found out that there are still very few attempts on in-situ upgrading (informal settlement upgrading) which would guarantee affordable housing. Therefore, the study opines that the National Bank of Rwanda could urgently address the exchange rate policy in order to make the mortgage market attractive to the teeming housing loan seekers. Non-commercial housing loans should be made available to all housing loan seekers. It would do a lot of good for both the national government and the civil servants if the salary structure is made responsive to both the inflationary trend and the dollar franc relationship. The Rwanda Housing Authority (RHA) ought to evolve some policy that would 
encourage loan acquisition by the civil servants and in liaison with BRD. Interest on housing loan should be below 5 percent.

Having observed that there is limited community involvement in the process of formulating housing policies as well as the design and implementation of housing projects in Rwanda, women and youth will need to be consulted on the kind of houses they will want to live in. More importantly, during the planning and provision of housing, their financial capacities need to be better understood. Although housing affordability is a complex subject in urban development, there was some consensus among the research participants. The comprehensive observation of affordable housing in Rwanda, was complimented by the empirical evidence from the surveys conducted as well as theoretical underpinning.

Interview results regarding strategies to facilitate provision of affordable housing are presented in Table 4. Out of the eight respondents, who had been selected owing to their all-round knowledge and experience of housing issues in Rwanda, a total five themes were garnered from their data, arising from 30 coding frequencies spread across the themes.

Table 4. Thematic analyses of strategies for facilitating affordable housing

\begin{tabular}{lcl}
\hline Strategy/theme & $\begin{array}{l}\text { Coding } \\
\text { frequency }\end{array}$ & Coding exemplars \\
\hline $\begin{array}{l}\text { Localizing policy } \\
\text { to enhance public }\end{array}$ & 5 & $\begin{array}{l}\text { In depth explanation of existing housing policies and translation into } \\
\text { the local language Kinyarwanda which is understood by the majority } \\
\text { citizens }\end{array}$ \\
$\begin{array}{l}\text { awareness } \\
\begin{array}{l}\text { Sensitizing } \\
\text { communities }\end{array}\end{array}$ & $\begin{array}{l}\text { To empower citizens with means to better comprehend their } \\
\text { purchasing power in relation to affordable houses and wise spending }\end{array}$ \\
\hline $\begin{array}{l}\text { Home buyers' } \\
\text { protection from } \\
\text { real estate } \\
\text { investors }\end{array}$ & 4 & $\begin{array}{l}\text { To improve awareness of citizens on their rights to adequate housing } \\
\text { and regulating the prices set by real estate investors }\end{array}$ \\
\end{tabular}




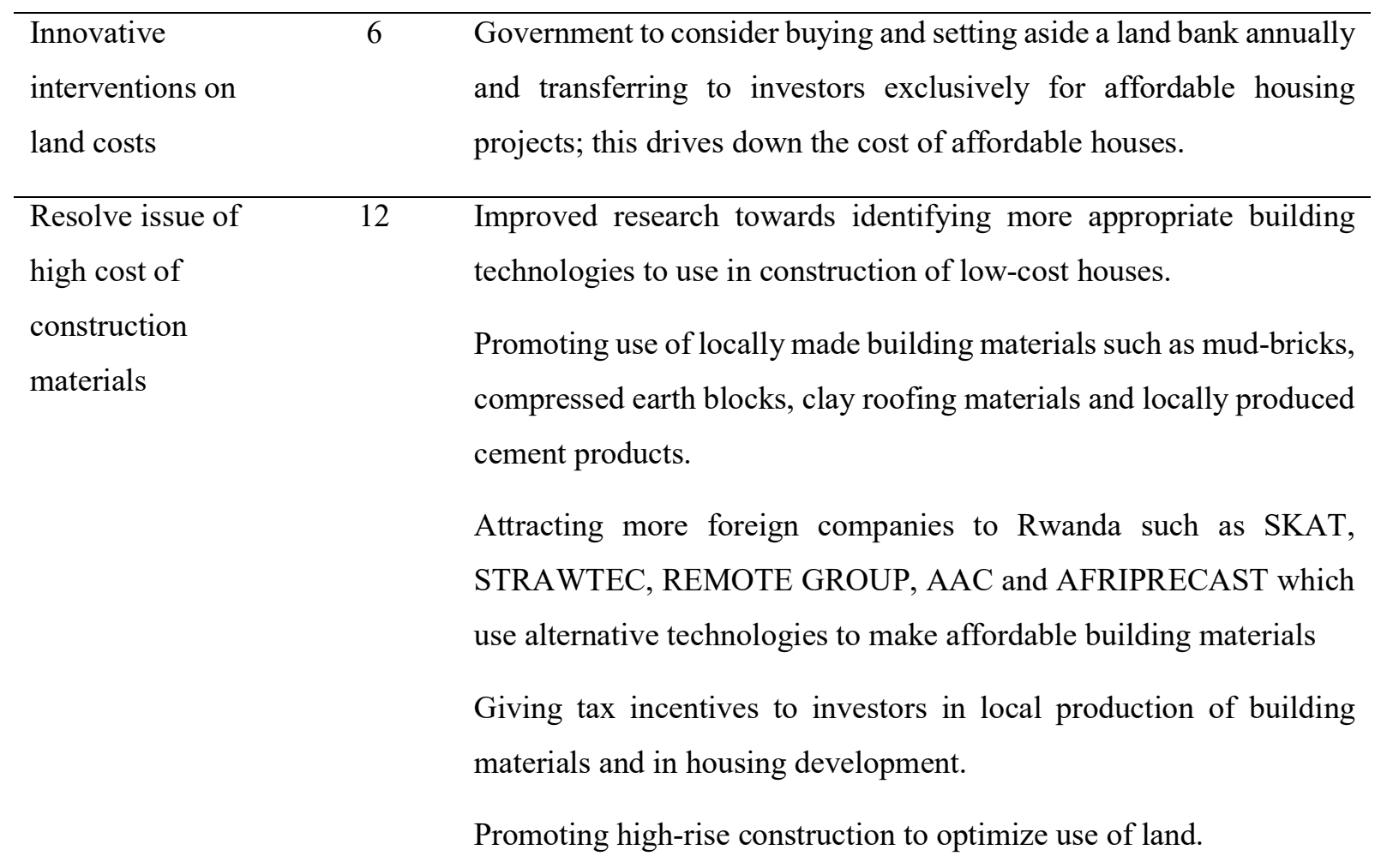

Source: Authors

After a thematic analysis of the responses received, resolution of high cost of construction costs and innovative interventions around land costs were ranked top two strategies for achieving affordable housing in Rwanda, as illustrated in Figure . Only 10\% of the coding frequency alluded to the thinking that sensitizing communities would impact on housing affordability. 


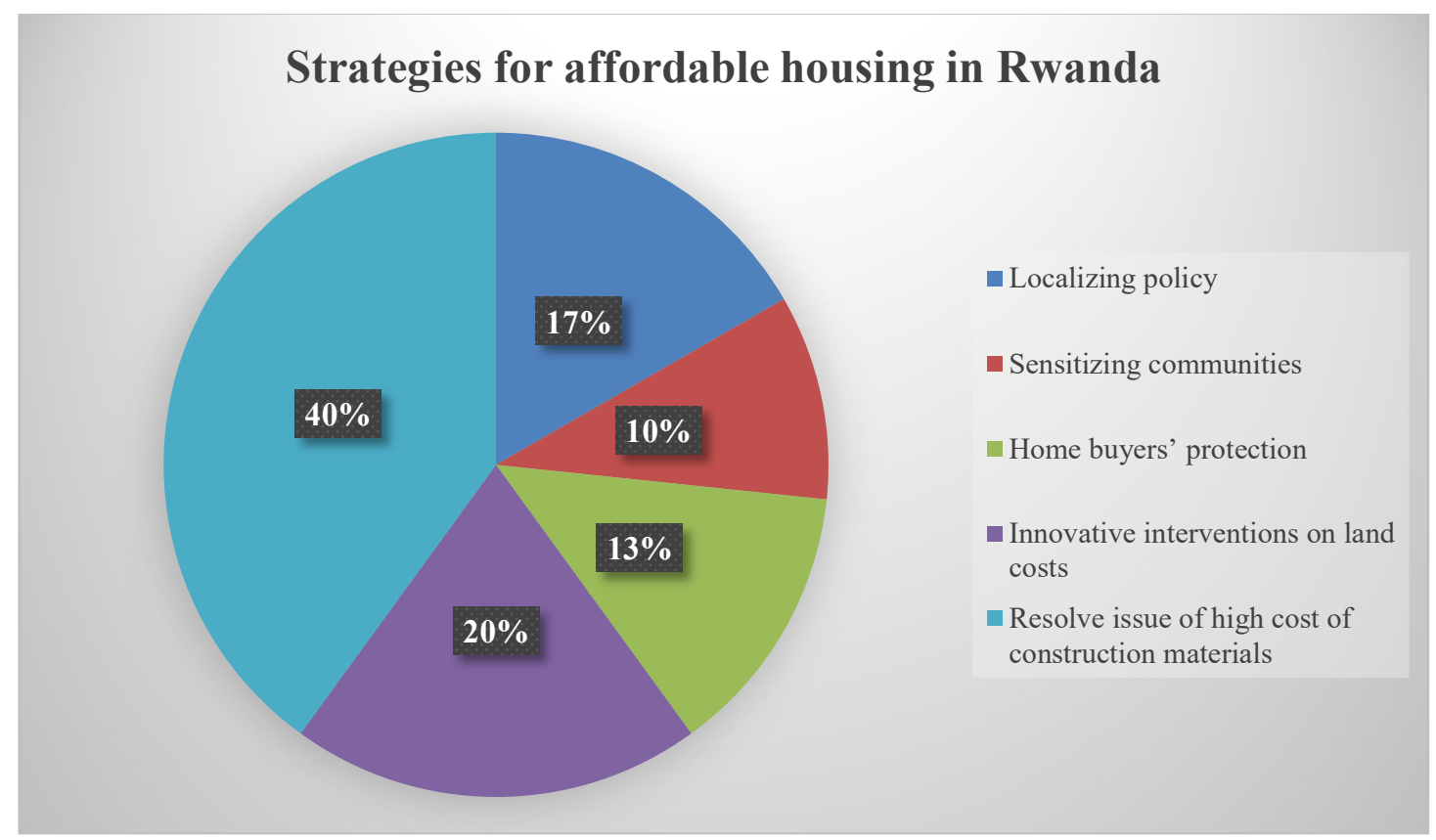

Figure 1: Strategies for affordable housing in Rwanda

Source: Authors

\section{Conclusion}

Housing affordability continues to be one of the key challenges in developing nations. Provision of affordable housing is therefore a vital task for any country and all stakeholders alike. This paper has explored the perspectives of housing affordability in Rwanda with a view of eliciting the challenges and facilitation strategies. It was observed that Rwanda embraced urbanization as a key priority through a number of policies aimed at ensuring sustainable housing. However, home ownership and tenure statistics in Rwanda largely varied with the largest being private households owned by the households occupying them. Four different segments of Rwanda's housing market existed but only one, the fourth segment, is able to access mortgage financing. The key challenges in providing affordable housing were found to be scarcity of cheap land, costly building materials, and lack of accessible housing finance. Among the potential facilitation strategies would be for the national government to avail salary structures that are responsive to both the inflationary trend and the dollar - to local - currency relationship. Community involvement in the process of formulating housing policies should also be improved. Identifying of appropriate building technologies for construction of low-cost houses could also help in lowering the cost of housing. It is hoped that 
this study will remind and at the same time better inform relevant policy in terms of formulating a way forward for improving the availability of affordable housing.

\section{Acknowledgement}

We are grateful to both the University of Rwanda and Makerere University for granting the authors time to undertake this research.

We are also grateful to the University of Nairobi for accepting our paper for a conference presentation in September 2019, and the paper reviews received.

\section{References}

Acolin, A. and Green, R. K. (2017). Measuring housing affordability in São Paulo metropolitan region: Incorporating location. Cities, 62, 41-49.

Adesoji, D. J. (2011). Urbanization challenges and housing delivery in Nigeria: The need for an effective policy framework for sustainable development. International Review of Social and Humanities. 2(1), 176-185.

Benken, E. E. (2017). Nowhere to go: informal settlement eradication in Kigali, Rwanda; University of Louisville, College of Arts \& Sciences senior honors theses.

Boamah, N. A. (2011). The macro-economy and housing credit market in Ghana. An International Multi-Disciplinary Journal, Ethiopia. 5(18), 25-39.

Bowe, J., Murray, S., Buckley,R., Wainer, L. (2019). Housing need in Kigali. Retrieved from https://www.theigc.org/wp-content/uploads/2019/07/Bower-et-al-2019-Final-report.pdf. Accessed 04.02.2020

Buckley, R. (2014). Affordable housing in Rwanda: Opportunities, options and challenges. The Centre for International Growth Conference, Rwanda National Forum on Sustainable Urbanization, Kigali March 21

Byusa, V. (2010) Chinese external assistance to Rwanda, AJOL, in https://www.ajol.info/index.php/rj/article/view/61852/49926 accessed $2^{\text {nd }}$ February 2020

Cai, W. and Lu, X. (2015). Housing affordability: Beyond the income and price terms, using China as a case study. Habitat International, 47, 169 - 175, 
Claude, T. J. (2015). Greening the real estate through sustainable housing development practices in Kigali City, Rwanda. Accessed on August 2019 at www.africaportal.org

Creswell, J. W. (2014). Research design : qualitative, quantitative, and mixed methods approaches (4th ed.). Los Angeles, Calif. ; London: Sage.

Curtis, J.R., Wenrich, M.D., Carline, J.D., Shannon, S.E., Ambrozy, D.M. and Ramsey, P.G. 2001. Understanding Physicians' Skills at Providing End-of-Life Care: Perspectives of Patients, Families, and Health Care Workers. Journal of General Internal Medicine. 16(1), pp.41-49.

Denscombe, M. (2010). The good research guide: for small-scale social research projects, GB, Open University Press.

Fellows, R. and Liu, A. (2009). Research methods for construction, US, Wiley-Blackwell.

Gan, X., Zuo, J., Wu, P., Wang, J., Chang, R. and Wen, T. (2017). How affordable housing becomes more sustainable? A stakeholder study. Journal of Cleaner Production, 162, 427 437.

Goodfellow, T 2014. Rwanda's political settlement and the urban transition: expropriation, construction and taxation in Kigali, Journal. of Eastern Africa. Studies. 8, 311 - 329.

GoR (Government of Rwanda), (2015). National Housing Policy. Accessed on July 2019 from www.rha.gov.rw/fileadmin/user_upload/Documents/.../National_Housing_Policy.pdf

Hsieh, H.-F. and Shannon, S.E. 2005. Three Approaches to Qualitative Content Analysis. Qualitative Health Research. 15(9), pp.1277-1288.

HUD (2007). Affordable housing needs 2005: Report to Congress. U.S. Department of Housing and Urban Development. Retrieved from https://www.huduser.gov/portal/publications/affhsg/affHsgNeeds.html, April 2019.

MININFRA 2008. National Urban Housing Policy for Rwanda; Ministry of Infrastructure. Kigali-Rwanda.

MININFRA, 2009. Update Version of the National Human Settlement Policy in Rwanda, Ministry of Infrastructure, Kigali-Rwanda.

National Bank of Rwanda (2019). Accessed in August 2019 from https://www.bnr.rw/home/ Nkubito F. (2016). Impact of zoning-based planning systems on housing affordability for the urban poor: The case of Kigali city, Rwanda. Master Thesis, School of Environment, Education and Development, University of Manchester. Retrieved from 
http://dr.ur.ac.rw/bitstream/handle/123456789/147/Nkubitoper cent 20Fred-

2.pdf? sequence $=2 \&$ isAllowed $=\mathrm{y}$.

Nubi, T. O. (2000). Housing finance in Nigeria. Need for re-engineering.

Olayiwola, L. M. (2013). Need for affordable housing provision for Nigeria populace. A paper at a 2-day National Seminar, the Nigerian Institute of Quantity Surveyors, Osun State, Nigeria.

Ram, P. and Needham, B. (2016). The provision of affordable housing in India: Are commercial developers interested? Habitat International, 55, 100 - 108.

REMA. (2013). Kigali state of environment and outlook report 2013. Rwanda Environmental Management Authority. Kigali.

Saunders, M., Lewis, P. and Thornhill, A. (2016). Research Methods for Business Students. 7th edn. Harlow: Pearson education

The World Bank. (2018). Rwanda affordable housing finance project (P165649). Washington DC 20433, the World Bank.

Tze, S. O. (2013). Factors affecting the price of housing in Malaysia. Journal of Emerging Issues in Economics, Finance and Banking (JEIEFB). 1(5), 417-421. 